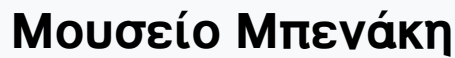

A Singular Antiquity: Archaeology and Hellenic Identity in Twentieth-Century Greece

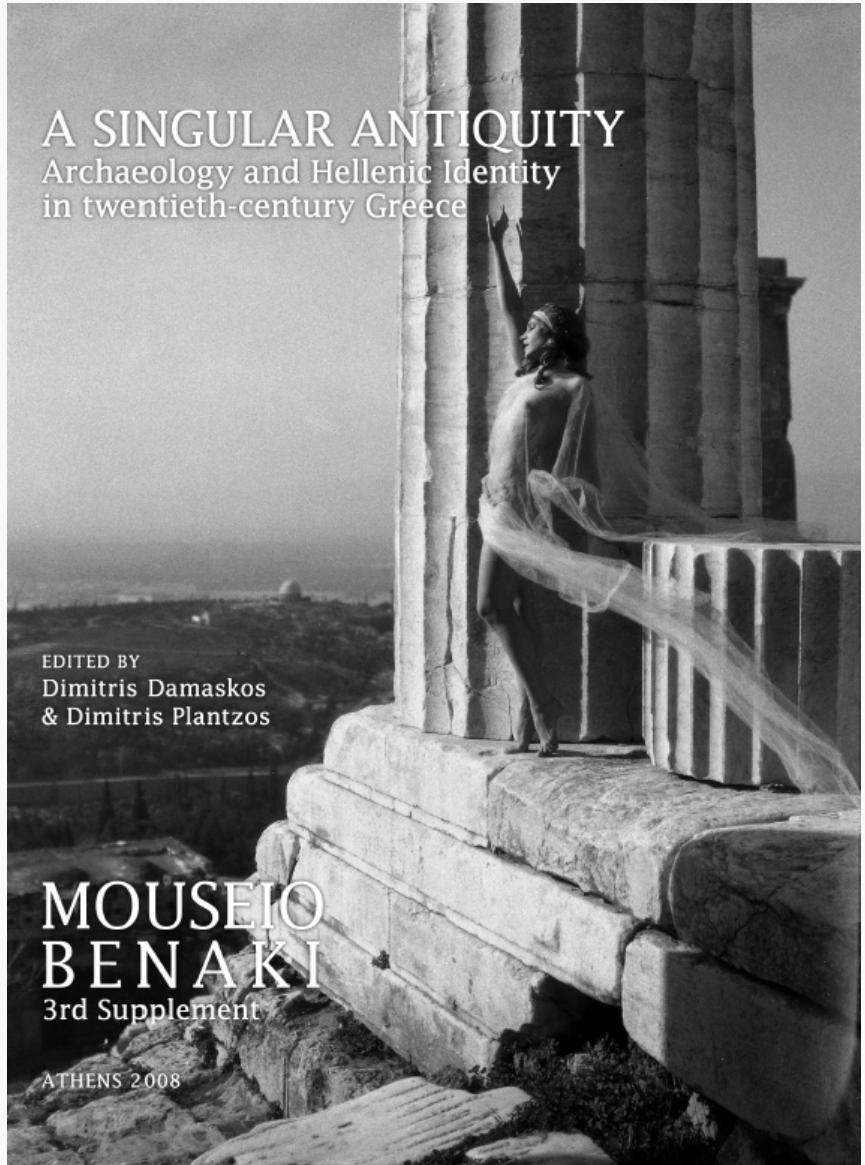

Time and the Antique: linear causality and the Greek art narrative

Dimitris Plantzos

doi: $10.12681 /$ benaki.18041

Copyright $\odot$ 2018, Dimitris Plantzos

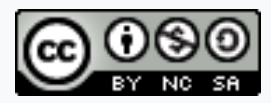

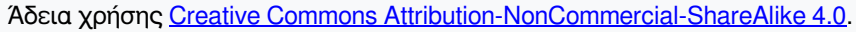

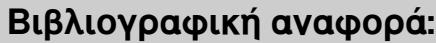

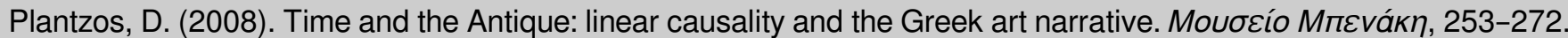
https://doi.org/10.12681/benaki.18041 


\section{Time and the Antique: linear causality and the Greek art narrative}

SINCE ITS EARLY DAYS, the Greek state has found in archaeology its ideological foundations and the implements of its international strategies. The development of a national - Helladic, as opposed to 'Greek' or 'Classical' - archaeology offered to the newly established kingdom a welcome repertoire of symbols and devices.

Archaeology, and its ever so eager practitioners, worked for the promotion of a crucial ideological premise, that of the historical and cultural continuity of the Hellenic nation, from the glory that was prehistoric Greece to the future triumphs of Hellenism (albeit via the misfortunes and tribulations of the present). ${ }^{1}$ In 1852, Kyriakos Pittakis, a veteran of the War of Independence and a self-taught archaeologist, published his first in a series of papers entitled 'Materials to be used to prove that the current inhabitants of Greece are descendants of the ancient Greeks.' This cumbersome but remarkably eloquent title does not try to hide the simple tactics of the project: page after page, Pittakis' papers list popular practices and sayings of his time which he associates, at face value, with seemingly similar ones he had found recorded in ancient literary sources. The author does not discuss, nor does he offer additional argumentation; the mere juxtaposition is presumably expected to speak for itself, driving home an otherwise self-evident
'Take the essence of the metaphor to be comparison and the essence of the story to be time. [...] The engineer and historian do not deal in mere comparison or mere time, no more than poets or novelists do. Aimless comparison is bad poetry and bad engineering; one damned thing after another is bad fiction and bad history. The point is pointedness, which will vary with the purpose in mind. (The point, incidentally, need not be simple or realistic or of any other kind especially approved by the nineteenth century)'.

D.N. Mccloskey, History, differential equations, and the problem of narration, History and Theory 30 (1991) 21.

point. This noble effort to substantiate 'scientific' claims regarding Greece's Hellenic past demonstrates, to paraphrase Arjun Appadurai, ${ }^{3}$ the 'notably synaesthetic and largely pretheoretical' strategies of a determined Greek scholar faced with the political and ideological challenges of modernity.

The launch, by Konstantinos Paparrigopoulos, of a tripartite scheme for Greek history (antiquity - Byzantium - modern Hellenism) ${ }^{4}$ and the contemporaneous 'discovery' of Greek prehistory by archaeologists such as Christos Tsountas 5 in the last decades of the nineteenth century, determined the agenda of Greek archaeology for the twentieth century: to unearth the 'missing links' in the evolutionary chain of Hellenism and investigate a historical development, the individual stages of which led inevitably to the present, plausibly also anticipating the future of this new (though ever so old!) nation.

Following the early attempts by pioneering enthusiasts such as Pittakis, Greek archaeology benefited from academic developments abroad, when the positivist paradigm, perfected in Western Europe - mostly Germany -, was imported by Greek archaeologists who had studied under the great European archaeologists of the time. The new paradigm had been specifically designed to facilitate 
the study of grand continuities and the composition of the appropriate interpretative narratives. The main beneficiary proved to be Greek - Hellenic - art, in its many facets: prehistoric as well as classical, Byzantine and 'post-Byzantine' Greek art was explored and largely exploited through a simple, and at times quite simplistic, linear art historical narrative, which haunts Greek university curricula to the present day ${ }^{6}$ (and is certainly not absent from many an 'established' university department worldwide).

As will be argued in the last part of this paper, our reasons for maintaining a linear perception of (art-)historical time are fundamentally political, and ought to be attributed to the peculiarities of modern Greek ideology rather than the academic needs of our chosen discipline.

Paragons and principles

Classical archaeology as an academic discipline in the twentieth century reaped the benefits of the philosophical heritage of the Renaissance and the Enlightenment. As a result, it was seen as a branch of Classics rather, and far less than, if at all, as a clear-cut archaeological science. The emphasis on the research of classical culture - history, literature, and the arts of Greece and Rome - is intensely reminiscent of the Renaissance, when the study of cultural remains from the classical past was thought to document the picture emerging from the ancient texts, themselves recognized as authentic sources of information regarding the past.

On the other hand, classical archaeology emerged as a fully-fledged discipline at a time of rapture with the past, when a new way of thinking, a new ethos, was emerging, that of modernity (which was the point of construction of all so-called 'Human sciences').? This kind of modern thinking, largely based on historicism and a positivist approach to humanism - in many ways departing from the heritage of the Enlightenment - still dominates classical archaeology. Its practitioners today seem more or less satisfied with their discipline's vaguely humanist pedigree, but also very much reluctant to proceed to a rethinking of its academic reasoning and methods, in order to produce a kind of 'theory' for classical archaeology. As a result, most of us remain confined within the limits of an academic tradition which we promote, recycle, or sub-consciously tamper with, surrendering to empirical reasoning and other, largely non-academic, influences. ${ }^{8}$
Although not modernity's sole agent, ${ }^{9}$ it has to be admitted that the Enlightenment project provided cultural history with both its fundamental ideology and the premise for its methodology. The 'noble, optimistic, rational doctrine and ideal' of the Enlightenment, ${ }^{10}$ was constructed upon a series of strong and axiomatic convictions about humanity and human civilization, a repertoire of beliefs today established as the natural basis of any historical or cultural inquiry. In short, these implicit principles are: the world - the universe, nature, man and man-made culture - is governed as a single entity by a single set of laws, natural, systematic, and rational; that humans - of any race, time, or place - are capable of improvement, progress, emancipation, and (ultimately) happiness; and that - as a result - it is possible to establish an ideal society, merely through rational thinking, understanding of and compliance with the natural laws which both the cosmos and man are subject to. ${ }^{11}$ It is, therefore, man's prime duty to decode, study, test, and apply those natural laws so that he can become the creator of his own happiness.

The influence of enlightened logic in the disciplines of history and archaeology is rather obvious, and can be traced in the assumed Cartesian foundations of Western scientific reasoning. ${ }^{12}$ The latter is responsible for a series of implicit principles and rules of present-day archaeological discourse, mostly the belief that scientific explanations are potentially absolute (i.e. to any given problem there can be only one solution, which is bound to overshadow any number of false solutions that may be proposed)..$^{13}$ The course of historical phenomena (the historical reality we are seeking to investigate), therefore, is subject to explanations based on causality (that is, a strict and linear understanding of the cause-and-effect relation) and teleology (in other words, the belief in the overall design, directive principle, or finality in nature or human creations). As a result, traditional archaeology promotes essentialist interpretations (that is, explanations based on the belief that certain attitudes or emotions are 'natural' or biologically endowed to race or gender). The construction of such scholarly narratives, promoted via a self-referential, introverted, and deeply conservative academic system, ultimately functions as a legitimizing device within contemporary Western societies, which in turn supports and promotes (through direct or indirect financing) this educational system in the first place. ${ }^{14}$

Thus, based on a pseudo-Cartesian paradigm, archaeo- 
logical science has been confident that the past could be understood in linear fashion, through a causal model linking the material remains to the culture that created them. Furthermore, it was understood that this model could be described and explained on the basis of the natural laws governing the universe (and historical time within it). This introverted self-sufficiency of modern scientific methodology soon turned archaeology into a thoroughly traditional episteme, cut off from developments elsewhere, until as late as the eighties, when post-processualism came to the fore. In the meantime, the cause-and-effect reading of historical phenomena had already been shaken off, in the early decades of the twentieth century, when Newtonian physics came under review, thus undermining the age-old Western conviction regarding the linearity of historical time.

\section{Natural and (art-)historical time: Newton to Beazley}

From as early as the thirties, scientific progress, particularly in physics, has had significant repercussions on the way we understand time - and accordingly the way we construct our relationship with the past. These breakthroughs, however, have had very little, if any, effect, on the methodology of disciplines such as history or archaeology, ostensibly themselves rooted in the paradigm imported from the natural sciences: that is, on the belief that time, and historical (or art historical) events within it, are subject to a natural law perfectly accessible to human intelligence.

The natural laws outlined by Isaac Newton in his monumental Principia Mathematica in 1687, combined with his very own law of gravity, seemed to provide the necessary tools in order to predict planetary movement. The Newtonian laws ended a long period of scientific inquiry initiated in the sixteenth century by Copernicus, whose work, however, was scarcely noticed by his contemporaries and only became more widely accepted a good deal later. ${ }^{15}$ The Newtonian view of the universe was timeless, deterministic, and objective, as his laws seemed to work with no reference to the observer or the scientist: a state of things aspired to by nineteenth-century scholarship.

Based on Newtonian physics, the French scientist Marquis Pierre-Simon de Laplace formulated the proposal, at the beginning of the nineteenth century, that the universe functions in a mode of strict causality, based on simple but strict laws, which govern its eternal, linear development, as well as human behaviour within it. In turn, according to Laplace, it would be possible, provided we understood these laws, to explain human history once and for all, that is to interpret the past, as well as predict the future; in other words, to compose the Newtonian equation of history. ${ }^{16}$ Laplace imagined 'an Intelligence who would know at a given instant of time all forces acting in nature', an Intelligence 'capable of subjecting all these data to mathematical analysis'. This entity - now dubbed Laplace's demon - could then 'derive a result that would embrace in one and the same formula the notion of the largest bodies in the universe and of the lightest atoms. [...] The past and the future would be present to its eyes'. ${ }^{17}$ Certainly, it was a phantasm, imaginary and demonic at the same time; though one created by a man's belief in science and his very own power of intellect. According to this reading, history was seen as a continuous, one-dimensional progression towards the triumph of reason. Historians were thus encouraged to think as scientists, accepting that under the same circumstances, the same data lead to the same results, therefore that history repeats itself. As historian Michael Shermer has put it, 'physicists chased the dream, and historians chased the physicists'. ${ }^{18}$

In the meantime, classical archaeology had acquired a 'scientific' method of its own, through the conscientious and systematic efforts of Johann Joachim Winckelmann (1717-1768). Winckelmann introduced to the study of classical art the device of stylistic analysis, both as a taxonomic instrument, through which a working classification of works of art might be achieved, as well as a key to the aesthetic appreciation, which was, according to him, vital to the historical assessment of any work. More significantly, he produced a stylistic account of Greek art, composing a chronological narrative, and a linear one at that: Winckelmann's take on style (his description of periods, trends, and individual artistic personalities) set the pattern according to which classical culture is classified and studied to this day: as an evolutionary, progressive scheme, structured through autonomous 'works' (usually referred to as 'masterpieces'), born of the genius of their respective 'creators' or 'masters'. This tautology results from the way Winckelmann equates a culture with its aesthetics. The latter is analyzed and classified on the basis of its style, based on independent cultural units taken to express, through the genius of their maker, the 'soul' of 
the culture he (very rarely she) represents. ${ }^{19}$ This proved an ingenious, and fruitful, attempt to reconcile the timeless world view promoted by the exponents of the Enlightenment with the modern grasp of real and historical time: through linearity, evolution and historicity.

According to Winckelmann's paradigm, art evolves towards an inevitable culmination, and then proceeds to an equally inevitable decline: in the case of Greek art, the moment of culmination was the art of Pheidias, whose style expressed the highest Greek ideal, what those sculptors before him could not achieve yet, and those after him could not achieve anymore. The scholar is able to know this course of things and judge the extent to which each artist conforms to these rules, so as to achieve the common goal of perfection. The scholar is thus cast in the role of what Laplace was going to imagine as a superhuman, intelligent being, his demon, able to follow the development of artistic phenomena, based on his/her prior knowledge of their predestined course.

Winckelmann's contribution was highly appreciated by his contemporaries - and his intellectual inheritance is strongly felt to the present day; his premature death was deeply mourned and his contribution to science promptly recognized: a copperplate engraving, for example, made soon after his tragic death, claims that 'in the midst of Rome Winckelmann lit the flame of the rational study of the works of Antiquity' (my emphasis). ${ }^{20}$ Still, individual artists were given a rather secondary role in Winckelmann's narrative: they are subordinate to the general laws of art and history, and are only implicitly admitted to influence the course of their art, through their understanding and application of the style of their epoch. This was a fundamentally Romantic, anti-Enlightenment attitude, based on regurgitated Platonism (in Ion, for example, the artist is described as the instrument of a higher power inspiring his creations) and widespread beliefs on the significance of the subconscious for the ways an individual artist, group, or nation express themselves. German nationalism, fervently championed by the likes of Friedrich Schlegel, Johann Gottlieb Fichte, and Johann Gottfried Herder, sought to base its belief in the superiority - historical, cultural, and spiritual - of the Germanic Urvolk (the primal people) on a new understanding of cognition and consciousness. Artists, like all other individual actors - single men or entire peoples - are thus seen as only half-conscious agents of superhuman forces, destined to express, through their personal idiosyncrasies, what is dictated to them by the powers that be. In total, a thesis that had a tremendous influence on German aesthetics and the way art is approached by many specialists or laymen to the present day. ${ }^{21}$

Classical archaeology turned to the individual (ostensibly the genius of the artist, though grasped through the genius of the scholar) only in the nineteenth century, and then only after certain developments had taken place elsewhere. The need to establish the individual as a free, intellectual agent in history, not subject to - but instigator and creator of - shifts in culture and art, was deeply rooted in Western humanism, but materialized rather late in Western thought and academic practice. According to Thomas Kuhn, it was a by-product of Copernican astronomical theory, or rather its dissemination (depicting as it did celestial movement as the result of the planets' individual careers in the infinite cosmos). ${ }^{22}$ For the French philosophers in the eighteenth century, history was the study of man's actions and knowledge, a science dedicated to great nations and great minds, kings and philosophers like themselves. This was the dawn of the age of the intellectuals in Western Europe, men of letters dedicated to thought, who were to act thereupon as the main shapers of the historical narrative, and were therefore entitled to reserve a principal role for themselves in it. ${ }^{23}$ Artistic genius was soon to be recognized as the true driving force in art, following Kantian teachings, and scholars became determined to enforce a positivist model in their investigation of the lost agents of history. ${ }^{24}$ At the same time, the concept of the avant-garde, referring to political radicalism as well as art, emerged in the writings of intellectuals such as Henri de Saint Simon in the 1820s, who cast the artist in a prominent role in the construction of the ideal state, promising a future golden age, a bourgeois heaven of prosperity. ${ }^{25}$

Based on the rationalist paradigm, scientific language was treated as a neutral, objective means of describing reality, and nineteenth-century philologists, historians and archaeologists strove to achieve exactly that: to clarify the past. An anthropocentric reading of the past thus developed, based on the study of creations (artefacts or historical events, works of art or literature, military campaigns and revolutions, inventions and ideas) and their creators. ${ }^{26}$

Since those early days, the turn of events has been rapid indeed. Ostensibly rooted in rationalism, the new approach was emphatically empiricist, a development that 
can be reasonably explained in the ideological milieu of nineteenth-century Germany. The emergence of German Romanticism, in conjunction with current political events, had led to the gradual disaffection among German intellectuals with the Enlightenment project. Art (or rather individual works of art) was seen as expressions of men or groups of men in a certain moment in history. German nationalism left its deep trace on aesthetics, as we saw above, as did the notion of the German people being related to the Greeks, albeit in a mystical, abstract way. ${ }^{27}$

The investigation of cultural phenomena is thus turned into a quest for individual 'works', and the study of individual 'authors' replaces that of their era - as it is a priori accepted that the master not only expresses, but also influences his time. In his effort to understand and classify ancient styles, Winckelmann had adopted the scheme applied to the study of Renaissance art, thus using the notions of 'author' and 'work' as methodological devices, analytical instruments in the service of his method. This application was maintained and expanded in the nineteenth century, and consolidated in the twentieth century through a series of mainstream classical archaeological projects such as the study of the so-called 'Roman copies' and (or for the most part) the attempted classification of artworks according to their perceived creators, based on stylistic analysis and to a much lesser degree on iconographical or other criteria.

Academia was soon conscripted to support a return to the Greek past: in 1810, Wilhelm von Humboldt founded the University of Berlin, where emphasis was placed on classical philology and classical archaeology, with the establishment of the first German chair in the subject. ${ }^{28}$ For German archaeologists of the late nineteenth century, a work of art was the voice of an individual artist expressed through his style. Though never stating explicitly what style was, they seemed to adopt the empiricist practice promoted by contemporary philology or history of art. ${ }^{29}$ In his monumental Meisterwerke der griechischen Plastik, published in 1893 and revised in English in 1895, Adolf Furtwängler approached Greek art (specifically sculpture) as a 'long course of stylistic development', ${ }^{30}$ articulated in terms of individual works and their authors. He is the first archaeologist to use the term connoisseurship, which he actually projects back to antiquity ('die Kenner im Altertum'). ${ }^{31}$ His reading of art history is at the same time teleological and anthropocentric, to the extent that it professes to establish a line of continuity through the development of art instigated by individual geniuses who could sense where that line was actually taking them. Furtwängler calls his method 'scientific' and feels accordingly justified in discarding the views of other scholars as 'demonstrably false'. ${ }^{32}$ Methodically, he guides his connoisseur's gaze towards the seemingly insignificant anatomical details in a work of art (a finger here, an ear there) claiming to be able to insulate his methodological tools from the theoretical framework in which they are conceived and applied, in an attempt to support the 'scientific' character of his project.

These henceforth autonomous 'works' become, as it were, the bricks in a Lego-set with which to construct a cultural-historical narrative; their attribution to respective creative entities - 'makers', 'authors', 'artists', 'masters' - facilitates the structuring of information in chronologi$\mathrm{cal}$ and geographical terms (since men are by definition confined to specific times and places). By doing this, we invest our narratives with the integrity of personal authority (that of the dead 'author', to be sure, as well as that of the very much alive 'specialist' - ourselves - at the same time), a gesture with ideological but also practical implications. It is, for example, indicative that from as early as the nineteenth century we have insisted on referring to random assemblages of artefacts, produced by collecting practices or the accidents of excavation - Alfred Gell's 'distributed objects' -, as bodies ('corpora'): a term implying organic integrity, charged with a particular ideological meaning, which encourages prospective students to confine themselves within preset boundaries, in order to achieve thoroughness and comprehensiveness. ${ }^{33}$

From as early as the Renaissance, but mostly since the eighteenth and nineteenth centuries, those literary sources surviving since antiquity were seen as the solid foundation of classical studies, an authentic and authoritative, transparent and irrefutable testimony on the ancient world, bound to be exemplified, supplemented even, but rarely challenged by the study of material remains. The artefactoriented study of the past led to the individualization of the 'work' as a bearer of first-hand cultural information, making it the subject of research rather than its tool. The emergence of philology in the nineteenth century as the champion of modern epistemology led to the recognition of linguistic significations as solid values, penetrable by a kind of positivist science. Ernest Renan, an orientalist philologist of the nineteenth century, who explored in his many writings the way philology and modern culture are 
both interconnected and interdependent, claimed in 1848 in a work entitled The Coming of Science that 'the founders of modern mind are philologists'. 'What is modern mind?' he asked himself. What if not 'rationalism, criticism, liberalism, [all of which] were founded on the same day as philology?' ${ }^{34}$ As a result, the scientific logos was objectified, it was seen as an infallible tool with which to describe reality. The essentialist approach to the text turned it into the bearer of authentic meaning against which all other indices of human experience were to be tested. In the words of Michel Foucault, 'the truth of discourse is caught up in the trap of philology'. ${ }^{35}$

In this sense, artefacts - works of art in particular (works of sculpture, painting and vase-painting, architecture even) - are treated as texts, agents, that is, of textual information. In order to decode these texts, and harvest the embedded meanings, classical archaeologists need only read the language they were composed in, what we generally refer to as 'style'. The quasi-Newtonian methodology constructed by the fathers of archaeological empiricism in the late nineteenth century and the early decades of the twentieth, combining factual observation with preconceived notions about humanity and history, has been shown to have been founded on 'a naïve, pre-Kantian metaphysics that promised the discovery of objective truths through the deployment of formalized and standard methodologies. ${ }^{36}$

This empirical approach to Greek art (based on the mystic notions of the hand of the artist and the eye of the scholar) was significantly developed by Sir John Beazley (1885-1970), Professor in Classical Archaeology and Art at the University of Oxford between 1925 and $1954 .{ }^{37}$ His papers on individual Athenian vase painters (and to a lesser extent potters) set a magisterial precedent in Greek archaeology studies, took full advantage of connoisseurship as a method to identify ancient styles and their creators, and - one could claim - seemed to take this approach to its limits. (Beazley's followers certainly did.) As John Boardman has put it, often enough 'the study is an end in itself'. ${ }^{38} \mathrm{~A}$ hard-core essentialist, Beazley famously insisted that 'the name of the painter [...] is of little importance; what interests us is himself and his style', ${ }^{39}$ a statement that would make Lyotard shriek, had he been interested in Greek vases. His aim was to identify each artist's individual traits, affectations and idiosyncrasies, which were thought to construct his personal style, a discovery then used to attribute anonymous works to their discernible masters.

It should be noted here, of course, that since those early days classical archaeology has indeed evolved in many respects - many branches of the discipline have benefited from developments elsewhere, such as the fields of social anthropology or geography, and they do not seem at all influenced by what I am describing here. Nevertheless, the art historical paradigm is far from obsolete in classical archaeology at large. As a matter of fact its employment seems to be being expanded rather than curtailed. In the past twenty years or so, its use has been exported from the fields traditionally associated with it (such as the study of classical sculpture and painting for example) to the rather unsuspecting fields of prehistory - in addition to the 'art historical' field of Cycladic sculpture, for example, connoisseurial arguments have been imported into the subfields of Mycenaean and Minoan pottery and seal-cutting - or the archaeologies on the periphery of the old classical canon, such as the study of Roman Britain or Spain, not to mention numismatics or epigraphy. When such reasoning is incorporated into the reading of entire sites, then it becomes apparent that the linear art historical narrative of Greek art is not only alive and well, but positively thriving, and that 'style' is still for us, classical archaeologists, pretty much a textual entity, open to our critical discourse (or rather transparent to our educated eye).

What is style? In a discipline which takes pride in its aversion to theory, it is not surprising that such definitions are not forthcoming. 'Style' remains a vague word put to a number of disparate uses; ${ }^{40}$ for many, especially art historians, treatment of style is voluntarily subject to aesthetic appreciation (whereas for others, cultural anthropologists mostly, it is forcibly dissociated from such projects). Judging nonetheless by the way in which stylistic observations are usually incorporated into the composition of art historical narratives, we may conclude that style is perceived as a strictly personal mode of expression, declared through a system of artistic devices, idiosyncrasies and preferences. ${ }^{41}$

In a ground-breaking, though subsequently rather overlooked, paper published in 1922, Beazley - at a time when he was embarking on his life-long endeavour of identifying and studying the 'hands' of Athenian vase painters of the Archaic and Classical period - formulated the Laws of artistic creation. ${ }^{42}$ 
He defined, first, a given work of art ('a substantive work') as the sum of what he referred to as execution, renderings (or actually the system thereof), and the design overall:

$\mathrm{W}^{\circ}=\mathrm{E}+\mathrm{R}+\mathrm{D}$.

In the same vein, a copy was defined as the ratio of execution to the sum of renderings plus design:

$\mathrm{W}^{\mathrm{c}}=\frac{\mathrm{E}}{\mathrm{R}+\mathrm{D}}$

Finally, a variation on a given work, what he referred to as a translation, was described by Beazley as the ratio of the sum of execution plus renderings to the overall design:

$\mathrm{W}^{\mathrm{t}}=\frac{\mathrm{E}+\mathrm{R}}{\mathrm{D}}$

These Laws of Artistic Creation according to Beazley where he obviously tries to invest his axiomatic statements with the authority of a natural law - expressed in algebraic form nonetheless - are clearly influenced by both the letter and the spirit of Newtonian physics. Furthermore, his Laws are fundamentally historical, as they strive to endow a series of empirical observations and connoisseur-like subtleties with the strength of a scientific law - no matter how experimental - regarding the artistic creative process. Beazley's equations are historical, for one because they emphasize systemic action within his chosen field of study; more to the point, his formulas are story-like as they attempt to organize artistic creation, as well as its reception and experience in time, present in these equations in an implicit, though extremely poignant way: the notion of creative process in itself presupposes the notion of time, and its every rerun repeats the equation, therefore creates further time.

As in Newtonian laws, time is spoken of in a quiet manner; its presence is implicit, but strongly felt. ${ }^{43}$ In the Second Law of Motion, for example (also known as the Basic Law of Mechanics), Force equals mass times acceleration: $\mathrm{F}=$ ma. Each such equation is a metaphorical expression (composed by a physicist) of a narrative that is explicity historical: here, time is implied by what the physicists call acceleration, defining the next step in the story, thus bringing us closer to history. In Beazley's laws, time hides under such terms as rendering, design, execution, all terms suggesting action and its repetition. The archaeologist is thus called to implement this metaphor, by repeating (notionally) the individual stages in the artistic process. Each new equation - fed with the result of the previous one - brings us closer to history, assessing human experience through time. This is an engineering model, known in mathematics as a differential equation: a differential equation involves the rates of change of continuously changing quantities modelled by functions; it is employed whenever a rate of change (the derivative) is known but the process originating it is not. This is a very old kind of mathematical reasoning, developed in parallel by Newton and Leibniz in the last decades of the seventeenth century and fiercely claimed by their followers on behalf of their respective champions. In historical terms, the stories narrated by such equations are inexplicit in their meanings: it is the analyst that makes them explicit, that is the historian - or in our case the art historian/connoisseur. ${ }^{44}$

This interpretation of art historical reasoning is, I believe, of crucial importance for the assessment of stylistic analysis as an archaeological discourse: although based on science, and the way mathematics and physics in particular viewed the development of such phenomena since the days of Newton, it is now known that such systems are not subject to linear development, therefore their evolution may not be studied - let alone predicted - based on linear reasoning.

According to the principles of the art historical methodology, keenly applied by classical archaeology since as early as the 1870 s, style is understood as an interactive system of ideological and modular variables, what in physics is called a dynamical system. The causal relations within such a system evolve through time and may not be studied, therefore, based on a static model merely describing their state at a given moment in this process. Dynamical systems and their structure (which is subject to a new sort of non-linear causality) are now studied by the widely known 'chaos theory': though not technically a theory as such, but rather a set of considerations on the non-linearity of dynamical systems, 'chaos' is a methodological device, a paradigm through which physicists are trying to comprehend randomness and predictability in nature.

Since the sixties, successive observations and discoveries have led scientists to the conclusion that dynamical systems, hitherto thought to be subject to the laws of linear causality, in fact evolved in a much more complicated manner, prone to randomness and non-predictability. ${ }^{45}$ Chaos has helped to revise causality, since: systemic phenomena appear to be sensitively dependent on initial conditions; cause and effect may not be directly proportional - rather subtle 
diversions (or 'errors') in initial or intervening conditions create grossly disproportionate results; natural phenomena are not deterministic (nor linear) and therefore may not be treated as predictable. ${ }^{46}$ Incidentally (though crucially) this is an inherent feature of dynamical systems and not an unforeseen and unfortunate error in their build. ${ }^{47}$

Furtwängler, Beazley, and many an art historian to the present day, envisage time as a serene field of action, not perturbed by the anxieties of irregularity or the frustrations of 'little' history. Bernard Berenson (1865-1956), ${ }^{48}$ for example, a cosmopolitan art critic and connoisseur whose knowledge of Renaissance painting gained him high acclaim in the inter-war period while his (dubious) liaisons with collectors and art-dealers gave him a rather bad reputation, pronounced in his Aesthetics and History (published in 1950), that 'history narrates the ordered succession of significant events that have contributed to making us what we are to-day'. ${ }^{9} 9$ The essay, an authoritative attempt to offer its author's views on art and history, albeit through the display of such a cavalier attitude as to make the reader wonder whether the famous connoisseur could muster any real grasp of either, makes a fundamental distinction between a Rankean history of irrefutable facts and an art history of values, and timeless ones at that: 'art history [...] has to do with masterpieces still with us, still appealing, as living entities, as manifestly active energies'.50 Overall, Berenson states that 'art history [...] is apt to pay too much attention to the "why" and not enough to the "how", ${ }^{51}$ thus clearly undervaluing his discipline's historical considerations in favour of its aesthetic ones. Though extreme, Berenson's example serves as a good reminder of the uses, ideological as well as political, that linear narrative was put to by twentieth-century art historians.

It is this timeless, a-historical reading of time that is the most problematic issue in such approaches. By the early twentieth century, physics had departed from Newtonian determinism, thus depriving positivists of their scientific pretence: based on the uncertainty principle, thermodynamics, and the laws of quantum mechanics, there emerges a model for our universe much more unstable, uncertain and complicated than Newton ever imagined. According to non-classical physics, cosmic matter is in a state of disorder rather than calm, and time is relative, quantifiable, and finite..$^{2}$

Time is thus understood as a consequence of entropy (i.e.: irreversible loss of energy), more a symptom of man's coming to terms with cosmic motion than an entity in itself..$^{53}$ In the second half of the twentieth century, some sociologists and philosophers were thinking along the same lines: Norbert Elias, for example, suggested in his essay Über die Zeit - written in 1970 but published only in $1984^{54}$ - that time is a social construct, devised by physicists in order to describe cosmic motion. Although Elias in his essay steered clear of physics - save for a few general mentions of Einstein - he identified the scientific questions regarding time from his own point of view: if non-classical physics is right on entropy and time, then human life itself, including the human conscience, is a consequence of the theory under scrutiny, therefore any promise of an 'objective' study of time (including history) is utopian.

Rather than suggesting a viable alternative to the study of human societies, even though the temptation of using physics as an analogy to history is indeed great, both with the classical/Newtonian and the non-classical branches of the discipline, the laws of physics are thus found to be human constructs, not god-given truths. Subject to the potentialities and limitations of human intellect, these formulations are attempts to describe - and therefore interpret - natural phenomena that exist beyond its control. Intriguingly, it has been argued that non-linear physics was widely accepted by the academic and intellectual establishment when it was, namely in the sixties, because until then the 'mechanistic view of the world served as a legitimating ideology for the project of dominating nature', and was therefore promoted by both the academia and 'extrascientific parts of society'. ${ }^{55}$ In a similar vein, it has been argued that chaos theory was a product of postmodern culture (and deconstructive literary theory) rather than the other way round..$^{56}$

Contrary to the determinism of a Newtonian universe, the quantum-mechanic paradigm allows for non-periodical movement, thus rendering causal mechanisms extremely complicated. ${ }^{57}$ Randomness eliminates predictability, in history as much as in physics. A strictly deterministic model presupposes that replication of the process replicates the result. The lack of linearity and periodicity within a dynamical system, of those two notional qualities, that is, that guaranteed its causal structure and predictable nature, leads to the conclusion that phenomena may not be repeated even in theory. ${ }^{58}$ Beazley thought that feeding his observations into his equations produced linear truth; now we know that feeding these data into the same equa- 
tions over and over again produces chaos. Our inability to repeat, even in laboratory conditions, natural phenomena, cancels out our favourite historical or art historical law: analogy. Analogies based on comparisons are used to classify events or artefacts, in an effort to extract metaphors that is, stories. Each such analogy takes the replicability of dynamical phenomena for granted. Quantum mechanics renders analogies redundant, however: perceived similarities or symmetries are there because they are perceived in the first place and, if tested, analogies may prove to count for little more than elaborate tautologies. ${ }^{99}$

Most general laws employed by Greek art historians today are based on a now obsolete mathematical model of static causality, leaving non-linearity, non-predictability, uncertainty and chaotic motion ${ }^{60}$ unaccounted for. $\mathrm{Hu}-$ man societies and their multifarious activities such as art are now perceived as 'immensely complex systems', $d y$ namical systems in a mathematical sense, where predictability is not an inherent quality. ${ }^{61}$ The endless number of possibilities and potential bifurcations in the development of even the simplest phenomena disables any all-embracing law that may be proposed. To put it in other words, the behaviour of a dynamical system could be explained by a general law, provided we had exact knowledge of initial conditions. It is a kind of trade-off, as historian George Reisch has called it, whereby: 'provided the laws which govern a chaotic system are known, the greater the temporal distance between initial (and intervening) conditions on the one hand and the event to be explained on the other, the greater the accuracy with which those conditions must be known'. The risk is, I believe, pretty obvious: lacking knowledge of initial conditions may take us way off course, to analogies that can only prove themselves.

As was observed by physicist Richard Feynman, half a century of research in quantum electrodynamics has shown that theory must be able to predict the errors inherent in the experiment. ${ }^{62}$ In other words, analogies, similarities, symmetries and so on cannot function even within a theoretical art historical model. At this moment, though we are able to describe how dynamical systems work, we cannot yet explain why they function that way. The Greek art narrative is based on a series of processes involving excavated and non-excavated artefacts (chronology, stylistic classification, ethnic attribution and taxonomy, attribution to workshops or masters), all subject to a strictly positivist-empiricist paradigm. This model of thinking presupposes a one-dimensional, timeless history, predetermined and concluded, based on the ceaseless and invariable repetition of historical phenomena. The attribution of specific works to known or devised artistic personalities is based on the forging of such a paradigm of linear development, a hypothetical mathematical model based on a one-dimensional cause-and-effect relationship. This model presupposes the continuous repetition of certain stages in the creative process (as new 'works' are mastered by the supposed 'author'), with no allowance for non-linear factors. The review of the linear-causality principle shakes the foundations of connoisseurship: very simply, whereas we may be able to explain why Painter A paints in Style X, we cannot prove that all works displaying Style $\mathrm{X}$ - and only those - have been produced by Painter A; and this, because we can no more argue that the same initial conditions (even in the event they were known to us) lead to the same results.

Connoisseurship, acting as one of the strongest pillars of a linear narrative for Greek art, derives its academic credentials from the individualism cultivated in Western thinking since the Renaissance, the essentialist approach to culture promoted by the Enlightenment, the ideologies championed by Romantic nationalism, and the methodology of the natural sciences in the nineteenth century. As was observed as early as 1963 by art historian Edgar Wind, 'it has repeatedly happened in the history of scholarship that a technique outlasted the philosophy that prompted it'. ${ }^{63}$ The reasons for this are rarely due to the validity of the techniques themselves; rather, their successful employment has created new academic realities, new intellectual modalities that establish themselves as the uncontested orthodoxy.

Rather than advocating, therefore, the replacement of an obsolete epistemological tool with another, by favouring a new kind of analogy with the natural sciences, this paper calls for a historical assessment of the theories we subscribe to, and investigation of our collective and personal motives, as a means of understanding our discipline before attempting, perhaps, to change it.

The dupes and the agents

It has been shown that Beazley owed his method to Italian connoisseur Giovanni Morelli (1816-1891), ${ }^{64}$ whose influ- 
ence has also been traced in the work of Furtwängler. ${ }^{65}$ The Morellian approach reversed hitherto traditional aesthetics by ignoring the obvious characteristics of a painting (composition, colours, expression, iconography) in favour of the subtle declarations of the artistic personality, such as renderings of anatomy, stylistic peculiarities, unconscious choices, or even mistakes. Though not all succumbed to this new cult of the individual, ${ }^{66}$ it seems that classical archaeology took a definite turn towards this whimsical mixture of idealist aesthetics with positivist method after Beazley, ignoring voices from other quarters. ${ }^{67}$ Beazley's Athens is constructed as an eclectic topos, with 'masters', 'workshops', 'circles' and 'schools', a Greek polis through Renaissance eyes, where the 'Kleophrades Painter may be said to play a kind of Florentine to the Berlin Painter's Sienese' ${ }^{68}$ It may be argued (and it has been), that this is an Oxbridge Athens, suitable for well-read academics such as Beazley, who sought, following the likes of Russell and Wittgenstein, to investigate the contribution of significant individuals to history. ${ }^{69}$ The persistence of connoisseurship in the second half of the twentieth century, aided by a general reluctance of historians of ancient art and classical archaeologists to engage in theoretical discussion, threatened to monopolize classical-archaeological studies; more to the point, it was exported, as we saw, to less 'art historical' subjects, such as prehistoric archaeology which was subjected to the same art historical approach. ${ }^{70}$

Critique has been levelled against Beazley's method on many different grounds, empiricist to theorist. ${ }^{71}$ By limiting ourselves to the study of individual styles, the general consensus of these critics seems to be, we restrict our research to the creative process and its mechanisms. We thus ignore vast areas of cultural integration, such as social reception and reading, use and misuse, dissemination and survival and so on, all excluding the artist's (or, more to the point, the craftsman's) involvement. Rather than being 'a system so definite, coherent, distinctive and in some respects so wilful, [that] is most easily intelligible as a personal system', ${ }^{72}$ style is to a great extent a social construct, a collective appreciation generated in the beholders' eyes, a dynamic balance that would, perhaps, surprise its 'maker. ${ }^{73}$ Only by departing from aesthetics - the 'burden of beauty' laid on most archaeological artefacts by Greek art enthusiasts - can we possibly understand the social significance of these objects, and of the events that produced them, that is, their social agency (whereby a socially significant quality of action - agency - becomes the focus of our study rather than the minutiae of action itself, the supposed 'facts' historians make a habit of chasing). ${ }^{74}$ If all we know about these shadowy figures comes from the works they seem to have produced, and which come to us one way or another, as excavators and looters would have it, why is it that we need to establish them as artistic personalities from a distant past? The answer of course lies in taxonomy, the perennial objective of modern science, and an inherent affectation of classical archaeology. Rather than being acknowledged, however, as an external descriptive tool applied to the material being studied by the taxonomist/connoisseur, style is promoted as an essential part of an artist's personality, thus masking the methodology followed by the 'specialist', and its ideological implications.

Nineteenth- and early twentieth-century scholars such as Furtwängler and Beazley vehemently refused to discuss theory. Insisting, as they did, that their strictly positivist approach could not be contaminated by subjective biases (such as personal thoughts or ideas), they claimed to see no reason to introduce theory in a seemingly a-theoretical process. This 'new way of making history'75 was more satisfactory, as it connected discourse to the eye and elevated commonplace observations to the status of scholarship, thus securing the functional efficiency of the scholarly approach, as well as state guardianship over heritage and its remains. ${ }^{76}$ The new stereotypes it created (among them 'the great artist' and 'the wise scholar' both still in currency) were instrumental for the new narrative of history and art, Greek, European or other, a history fit for mass consumption in a century that was going to celebrate exactly that: the will of the masses to consume. And quite appropriately, albeit rather ironically, it was the culture industry rather than the artistic avant-garde, so wholeheartedly celebrated by this particular strain of a relentlessly bourgeois episteme, that transformed everyday life in the twentieth century, and finally won the day. ${ }^{77}$

As historian Carlo Ginzburg has shown, ${ }^{78}$ connoisseurship utilizes a new epistemological paradigm that emerged in European episteme in the last decades of the nineteenth century, and affected primarily the field of the Humanities. ${ }^{79}$ Based on the speculative assessment of a mass of obscure, seemingly trivial or unrelated material, the rational individual retraces the past, thus turning the clues in his 
hands into a body of evidence. This new way of academic reasoning, called abduction, in effect invalidated Cartesian logic and Francis Bacon's inductive paradigm which had stood as the basis of Western philosophy and science since the seventeenth century. ${ }^{80}$ Reason was gradually, though surreptitiously, replaced by empiricist common sense (which for many twentieth-century art historians equals commonplace). This sentimental quest for the lost individual creator inspired a century of (mostly classical) archaeology where the symptom replaced the phenomenon ostensibly under study.

Abductive reasoning is based on prior acceptance of the linearity of cultural phenomena, as well as the power of human intellect to produce transparent (that is 'objective') and secure conclusions based on reason, judgement, and what we often call 'the expert eye'. This is in fact an exhaustive game of mirrors, whereby the repeated displays of intellectual skill finally render the paradigm invisible. ${ }^{81}$ Through quasi-scientific discourse - barely disguising purely metaphysical manifestations - the scholar appears as the agent of a seemingly transparent logos, one that qualifies itself. ${ }^{82}$ Our analogies attempt a representation of the phenomenon in mathematical terms: the scientific premise seeks to hide the fact that what is attempted is a representation in the first place, in other words 'metaphysical speculation disguised as an empirical science'. ${ }^{83}$ This is an attitude inherent in modernity, within which it presents itself in the field of science as well as in politics. ${ }^{84}$

Ginzburg is right to associate this phenomenon with political developments in Western Europe, where the central state wished to control, supervise and discipline its subjects. ${ }^{85}$ As has been argued by Michel Foucault, ${ }^{86}$ an all-seeing (panoptic) modality of power was essential to the bourgeoisie's attempts to claim a dominant political and social role for itself in the course of the eighteenth century, an endeavour masked by the Enlightenment project and the liberties it introduced. ${ }^{87}$ Academic reasoning was instrumental in this, and the philosophes of the eighteenth century, followed by their successors, the Professoren of the nineteenth, worked hard to create a bourgeois episteme which was to claim its rightful place in the century that followed. This was a new, quiet and discreet, humbly a-theoretical and ardently empiricist type of 'in-house discourse, ${ }^{88}$ accessible to all, since it aimed to please all, by producing a reassuring, innocuous and legitimate narrative for art and history. Difference was under strict surveil- lance and dissidence duly suppressed. As argued by historian Hayden White in 1987, linear historiography, which played a dominant role in the development of modern humanities, is ' the representational practice best suited to the production of the "law-abiding" citizen'. Linear narratives, he claimed, are especially well suited 'to the production of notions of continuity, wholeness, closure, and individuality that every "civilized" society wishes to see itself as incarnating, against the chaos of a merely "natural" way of life.' Just as modernity praised reason, regularity and symmetry, methodological consistency - 'the like treatment of like cases' - was prized as the guarantor of scientific coherence and stability, but in a bureaucratic sense. The desire to establish a rational ethos overall, in its Weberian sense, is evident in archaeology's claims to 'scientific objectivity': coherence, consistency, and effectiveness have long been identified as the ambitions of modern episteme, in an effort to establish long, linear, and reassuring historical narratives that 'make sense'. ${ }^{89}$

Modern art criticism, starting some time in the nineteenth century, proceeded to establish 'the author' as a figure central to our understanding of art and culture, contemporary or ancient. The process of what has been called 'the creation of the creator' ${ }^{\prime 0}$ has been well studied by many since the seventies, even though archaeologists and historians of ancient art seem reluctant to consider this line of thought. The quest for the Greek Master continued quite late into the twentieth century, even after the very concept of 'the author' in literature and art had been seriously challenged. In 1968, Roland Barthes had spoken of the death of the author, claiming that 'the author is a modern figure, a product of our society insofar as, emerging from the Middle Ages with English empiricism, French rationalism and the personal faith of the Reformation, it discovered the prestige of the individual'.$^{91}$ This concept was further explored by Foucault at about the same time. ${ }^{92}$ He traced stylistic studies of individual authors in the philologists of Late Antiquity, ${ }^{93}$ arguing that this ancient model influenced the modern field of the Humanities. As a result, the modern author is a taxonomic device, a classification tool used to harness the text rather than elucidate it. As an ontology, a 'human person', the author is used to eliminate inconsistency, to safeguard continuity and to express ideas said to be his own. In other words, he is the guarantor of linear and predictable history, an agent for causality in scholarly discourse, and 
a witness to the success of the modern epistemological paradigm. The more we speak of the genius of these artists, the more we burden them with modern concepts and ideas which we wish to impose on their time.

This brief analysis of twentieth-century scholarly mentalities explains, I believe, the enthusiastic interest archaeologists and art historians have shown for the lost artist. Certainly, 'pigeon-holing is an exercise in power. ${ }^{94}$ The scholar-detective that emerged as the stereotypical archaeologist of the twentieth century, shrewdly - albeit somewhat callously - assessing the disparate evidence in order to capture the elusive artist, ${ }^{95}$ owes as much to nineteenthcentury crime fiction (Ginzburg talks of Sherlock Holmes) as to police practices of surveillance in modern states. ${ }^{96}$ Capturing criminal elements (certainly in literature or on the T.V.), decoding the symptoms and reading the signs is a fascinating business indeed. Fredric Jameson has recognized in modern scholarship a 'self-referential, if not performative' trope, generating a quasi-libidinal intellectual excitement, 'a promise within a present of time [of] a way of possessing the future'. ${ }^{97}$ The excitement of conversing with the creators of the past - from Pheidias and Perikles to Alexander and Augustus - is a good incentive for the scholar in modern episteme, and is not likely to subside anytime soon. We are proud of the things we know and of the things we write, and when - including this paper - we refer to those before us as great authorities - from Furtwängler and Beazley to Barthes and Foucault - we are quietly hoping that someone will do the same for us in the not-so-distant future. History thus regains its causeand-effect succession, and reclaims its linear perspective. Though the philosophies that generated individualism and abductive reasoning in Western scholarship are now long obsolete, connoisseurship and similar empirical tools show remarkable signs of persistence. Unbeknown to us and our students, nineteenth-century science has never left us: 'and here we are again, far more than we know, both the dupes and the agents of a scientific age..$^{98}$

Having said that, I should admit that often enough, our empiricist dispositions get the better of our good intentions. Human experience is much closer to a Newtonian universe rather than a quantum-mechanic one. Hence, our feeling at ease with a theory that seems to coincide with our day-to-day experience. Human limitations, biological as well as intellectual, are binding for human science, and human intellect at large: the sense of time and space, size or distance are subject to the measure of humanity and the way we can, based on our natural endowment, comprehend the world far or near. This is all part of a universal human strategy - the anthropic strategy or principle as it has been dubbed by scientists - in order to tame the notion of life being the result of randomness (in other words, 'things ought to be the way we see them, for otherwise we would not be able to see them!'). ${ }^{99}$ Historians attempt a reversal of the causal development (holding onto the effect and searching for the cause). As a result, they create the illusion of historical necessity and linear development, leading unfailingly to a predestined future. This is corroborated by day-to-day human experience, where relativity manifests itself in an exceedingly subtle, therefore imperceptible manner. Archaeologists are thus trapped into an empiricist discourse, in a futile effort to explore the motionless body of an irrevocable past.

Post-script: Time and the Nation

Like anthropology, archaeology too can be described as an 'allochronic' discourse, a study of man-made culture produced elsewhere, at another time. ${ }^{100}$ Archaeology, like its sister-disciplines of ethnography, ethnology, and anthropology itself, was given its epistemological shape at a time when Western academia deployed the study of the past as an intellectual justification for colonialism and imperialism. ${ }^{101}$ Classical archaeology in particular, was used to forge the cultural links of the West with its lost Graeco-Roman childhood, the rediscovery of which made the state of modern Greece all the more deplorable. ${ }^{102}$ Constructing the Other as its object of study was vital for the colonialist project, as it guaranteed - through the forged distance in time and place - that the Other would remain silent, or in what has been described as a 'state of ab-sense'. ${ }^{103}$ Archaeology, detached and objective, was called in to perform the crucial role of producing the 'facts' needed in order to represent the past as an artefact available to 'scientific' scrutiny.

Connoisseurship is seemingly split in that respect, as it is dealing with historical phenomena of the past, thus concluded ones, while on the other hand its subject is art, which is by definition accepted by the connoisseur as 'eternal': a masterpiece of classical sculpture is recognized as such equally in fifth-century Athens and eighteenth- 
century Rome, and the style of an Athenian master vasepainter can gain him as much recognition in Renaissance Florence as in the Archaic Kerameikos (not to mention twentieth-century Oxford or New York). Connoisseurship thus transcends the temporal divide: the student and his or her object of study are perceived to co-exist in time, and a Newtonian - linear and absolute - time at that.

By means of this scientific premise, the Greek art narrative was constructed as an objective discourse, external to the observer, open to rational scrutiny, even though in practice it re-enforced the notion of the scholar as a mystic, imparting morsels of knowledge gained through tedious taxonomy, classification and decipherment. As an authoritative assessment of the past, this way of teaching history guarantees firm control over the present experience, reinforcing what Derrida called 'a metaphysics of presence. ${ }^{104}$ Positivist methodologies, such as attribution studies as outlined above, become effective by virtue of their pedantry; furthermore, they promote the reassuring conviction that the Other is accessible and predictable, at one's scholarly disposal. These methods have now been rightly exposed as 'regressive intellectually, and quite reactionary politically' ${ }^{105}$ 'Regressive', as they adopted, in order to achieve a quasi-scientific status, a Newtonian view of time only when, at the end of the nineteenth century, the limitations of Newtonian physics were becoming obvious to scientists. And 'reactionary', as their enthusiasts failed to observe (or pretended not to) that the results of their seemingly detached and transparent methodology were, historically and politically, anything but. Rationality has long been identified as a key intellectual issue raised by orientalist discourse in an attempt to define, isolate, study, and therefore control the Orient (including the 'classical lands') on behalf of Western episteme. ${ }^{106}$ It is also a useful discriminatory tool between 'them' and 'us', the subjects of study and its agents, especially when the former refuse to keep quiet. It is certainly no coincidence that disciplines like archaeology or folklore, promising to deliver 'absolute, context-free knowledge' emerged in the area of Greek studies simultaneously with empiricism; ${ }^{107}$ nor that this line of academic reasoning was adopted with enthusiasm by students of ancient Greek art in Greece itself.

By colonizing Greek antiquity, from the days of Philhellenism on, Western enthusiasts seemed to be paying a grand compliment to modern Greeks who, as has been observed by Michael Herzfeld, relished the superlative rhetoric while failing (strategically?) to subscribe to its underlying ideology. ${ }^{108}$ Archaeology has been one of the key projects through which to imagine the nation, in Anderson's now classic terminology, both as an entity external to the observer (i.e. in the case of Greece, from the point of view of the tutelary Powers at the end of the War of Independence) and as a collective experience from within. ${ }^{109}$ In the case of Greece, the latter would refer to the local Western-educated elites, which usurped the role of the absent colonialists, thus becoming the country's national(ist) bourgeoisie in their place, rendering national ideology and rhetoric in a state of 'self-colonization'. ${ }^{110}$ Critiquing Said's (and Anderson's) rather monolithic view that non-Western imagination was entirely and a priori colonized by the West, Lynn Meskell was right to suggest that local elites and other powers emanating from within the nation-state produced a multitude of centrifugal narratives, apparently not controlled by the colonialist centres. ${ }^{111}$

Classical antiquity, emblematized in the forms of Greek art - through the process of 'logoization' of culture common in nationalist projects ${ }^{112}$ - was treated as valuable national capital by the Greek elite, and at the same time became a powerful weapon to be deployed in the cause of Greek nationalism. ${ }^{113}$ In an effort to deny the rejection of modern Greece implicit in the promotion of classical heritage by the West, Greeks promoted the very same heritage in order to state, and quite explicitly so, that Greek modernity co-exists with Greek antiquity, both as a continuation of and a supplement to it. Locally identified as 'national', and internationally often misjudged as atavistic, projects such as archaeology are meant to confirm identities and reinforce national ties, inscribing the nation's locality onto the bodies of its subjects, a process that has been described as 'the production of natives'. ${ }^{114}$

Archaeology in Greece was given the task of producing the national subjects as well as the contextual framework for their expression, while at the same time serving the established culture and its rhetoric. The linear Greek art narrative, in particular, still promoted by most authorities in the country, inside and outside the university, has been tailored to fit the nation's needs: it is predictable enough in its readings to be accessible, but sufficiently cryptic in its manifestations to require 'the specialist'; it offers the necessary visual stimuli - based, as it is, on both tangible evidence and the aesthetic value invested in it - so as to satisfy the nation's 'longing for form'; ${ }^{115}$ it is teleological 
and deterministic so as to enforce the nation's belief in its singular merit and higher destiny; finally, it has been expertly designed - by some of classical archaeology's founding fathers - as a legitimizing tool and control mechanism promoting cultural chauvinism and social exclusion. At a time of new border conflicts in the Balkans and elsewhere, near or far, Greece reluctantly plays host to hundreds of thousands of refugees, asylum seekers, and illegal immigrants whose multicultural presence poses a severe threat for what Greeks universally perceive as their homogeneous community. We are bound therefore to witness a reaffirmation of Hellenicity, crucially involving classical and

\section{Notes}

* I am grateful to Professor John Boardman who read an earlier draft of this paper and offered me his thoughts, suggestions and encouragement. To Michael Herzfeld I owe a couple of important bibliographic references and to Antonis Liakos and Kostas Kotsakis many helpful comments and moral support. An earlier version was presented at Princeton, courtesy of the Hellenic Studies Program and its director Dr Dimitri Gonticas, and New York University at the invitation of Professor Joan Connelly; I am grateful to the audiences on both occasions for their encouraging response. The seminars were part of the Alexander Papamarkou Lecture Program 2007, funded by the Cycladic Art Foundation (New York). I wish to thank its President, Shelby White, for her kind invitation to participate in the Program, as well as Maria Tolis, Curator for the Museum of Cycladic Art in Athens, for her assistance with practical matters. It was, however, the late Dolly Goulandris who introduced me to the Program and put me through its motions; this paper is dedicated to her memory.

1. On archaeology and the Greek state in the 19th c., see Herzfeld 1986, 10-11; Skopetea 1988, 190-204; Peckham 2001, 115-36; Gourgouris 1996, 145-48; Hamilakis 2007, 57-123.

2. Kokkou 1977, 85-99; Skopetea 1988, 196 n. 20. Cf. Kalogeropoulou \& Prouni-Filip 1973, $\rho v \varsigma^{\prime}-\rho \xi^{\prime}$. Pittakis (1798-1863) was a pioneer of Greek archaeology and an ardent nationalist, whose vehement conflict with Ludwig Ross (1806-1859), a German and the first General Director of Antiquities after the establishment of the Greek state, and Jakob Philipp Fallmerayer (1790-1861), the Tyrolean journalist and historian who challenged the racial purity of the modern Greeks, gained him some praise in Greece though somewhat undermining his academic integrity. See Veloudis 1982, 31; Skopetea 1997, 43-62.

3. Appadurai 1996, 1.

4. Liakos 1994; Skopetea 1988, 179-89; Dimaras 2002, 391- pre-classical antiquity, no longer (or not so much) as ammunition against the cultural aggressiveness of the West, but as a discriminatory apparatus at home, safeguarding 'national purity'. The promotion of continuity in Greek culture, however, suggested by a linear art historical narrative for Greek art, classical or post-classical, can do very little to soothe the pains and frustrations of a society in a perpetual identity crisis, thus coming to terms with the end of modernity.

\section{Dimitris Plantzos \\ dkplantzos@yahoo.gr}

410; Voutsaki 2003, 232-37.

5. Voutsaki 2002.

6. Cf. Hamilakis 1992-1998.

7. Cf. Foucault 1984a, 39; Jameson 2002, 42-57; also Berlin 2000, 30-41.

8. On archaeology as a by-product of modernity, see Hamilakis $2004 \mathrm{~b}$.

9. On Romanticism and Modernity, see Berlin 2000, 27679; Berlin 1999, 21-45.

10. Berlin 2000, 278.

11. Berlin 2000, 276-79; Trigger 1989, 55-61.

12. As argued by Foucault (Foucault 1970, 50-58), the terms 'Cartesian', 'Newtonian' and so on, usually employed with reference to the modern episteme's tendency 'to make nature mechanical and calculable' are not true to the real nature of $17 \mathrm{th}$ c. rationality. Instead, he argues, the epistemic drive until the end of the 18th c. was to analyze the world as a structure with specific dimensions, governed by strict order. This sense of hierarchical - rational - order replaced the Renaissance determination to interpret the world. As a result, History (the study of the past in its entirety) was divorced from Natural Science (the study of the world). It was the emphasis on order and measurability that was retained by 19 th $\mathrm{c}$. science as the foundation of modern empiricism.

13. Cf. Johnson 1999, Ch. 11 where, however, modernity is seen as the exclusive offspring of the Enlightenment. Cf. also Hodder 1992, 275-80.

14. On Greek archaeology and education, see Hamilakis $2004 a$.

15. Kuhn 1985, 185-228; Prigogine \& Stengers 1984, 57-68. 
16. See Stewart 2002, 1-8; Hawking 1996, 55; Prigogine \& Stengers 1984, 75-77; Shermer 1995.

17. Quoted in Shermer 1995, 82-83.

18. Shermer $1995,83$.

19. See Shanks 1996, 56-59; cf. Potts 1994, 23-33.

20. Jenkins \& Sloan 1996, 147 cat. no. 30.

21. See Berlin 1999, 93-117.

22. See Kuhn 1985, 261-65. Though formulated in the 16th c., the findings of Copernicus were able to reach a wider public only long after his death; at the same time, the revival of Greek atomic theory seemed to encourage, in the philosophical-ideological field, the description of society as a gathering of individuals with inherent qualities and potentialities.

23. Cf. Darnton 1984, 190-97 on the philosophes and the Encyclopaedia; also 167-70 on the gradual emergence of intellectuals in European society. On 19th c. scientific empiricism, see Foucault 1970, 128-32; 303-43.

24. Borbein 1996, 66-67.

25. Huyssen 1986, 4-5.

26. When in 1887 Wilhelm Klein published his study Die griechischen Vasen mit Meistersignaturen in which he dealt with Greek vases signed by their potters and painters, his work was greeted by Camillo Praschinker, then Professor of Archaeology in Prague as an attempt to 'rescue the individuality of ancient artists from the shadows'; Rouet 2001, 28.

27. The main exponents of these ideas were the 'Fathers' of German Romanticism, notably Hamann, Herder and Schiller, who despised anything French, including the Enlightenment. See Berlin 1999, 58-67 (on art as expression in German Romanticism) and 87 ('Once upon a time we were Greeks').

28. See the analysis by Lyotard (1984, 31-37) regarding von Humboldt's ideological motives, for strengthening 'the intellectual character of the German Nation'; Borbein et al. 2000, 7-19.

29. See Rouet 2001, 36-40.

30. Furtwängler 1895, 199 (= Furtwängler 1893, 385). On Furtwängler's project, see Palagia \& Pollitt 1996, ix-x [Palagia] and 1-15 [Pollitt]. Cf. Childs 2005.

31. Furtwängler 1895,4 . Thanks to the newly developed tool of photography - to which he attributed absolute objectivity - Furtwängler was able to combine the empiricist approach of contemporary philological and art historical studies in Germany with earlier views on antiquity.

32. Furtwängler 1895, 42.

33. On style and the corpus see Gell 1998, 165-68; 221-23.

34. Renan 1890, 141 (written in 1848); see Said 1994, 12348.

35. Foucault 1970, 280-302 [297].
36. Fabian 1983, xvi [Bunzl]; cf. 3-4.

37. On Beazley and the 'method', see Kurtz 1985; Robertson 1985; Sparkes 1996, 91-102; Rouet 2001, 93-108; Boardman 2001, 128-38.

38. '...but equally a means to many other ends': Boardman 2001,128 , a statement repeated on p. 138 , where the author clarifies that 'before we are able to make [the method] work for us we need to understand it'.

39. Beazley 1910, 38.

40. Gell 1998, 155.

41. Cf. Beazley 1922, 80-84: 'They [forms] comprise both the master lines which in archaic art demarcate the several parts of the body and of the drapery, and the minor lines which subdivide or diversify the areas thus demarcated. We may speak, in fact, of a coherent, comprehensive system of representing the forms of the human body naked and clothed. [...] The system of renderings described above stands in a certain relation to nature. [...] Memorize the system, and walk through the Louvre or British Museum: you will not be in doubt on which vases it is present or on which it is absent. [...] A system so definite, coherent, distinctive and in some respect so wilful [...] the child, above all else, of one man's brain and will' (my emphasis).

42. Beazley 1922; Rouet 2001, esp. 104-8.

43. See McCloskey 1991 for a discussion of differential equations as story-like metaphors, and a discussion of the Second Law of Motion as an example of such an equation.

44. McCloskey 1991, 22.

45. See Lorenz 1996, esp. 3-24.

46. Cassidy 1992.

47. Cf. Lorenz 1996, 10-12; 102-10. The inherent non-linearity in the development of dynamical systems is commonly known as the 'butterfly effect' (subtle changes result in serious distortions of the data and alter the original dynamics). See Lorenz 1996, 181-84 for the first description of this paradox and Stewart 2002, 126-29 for further comments and exploration of the idea.

48. Brown 1979; Maginnis 1990; Kurtz 1985, 241-43; Sparkes 1996, 91-92. It is uncertain whether Beazley and Berenson had ever met, though they knew and admired each other's work, shared common interests and influences.

49. Berenson 1950, 222.

50. Berenson 1950, 200.

51. Berenson 1950, 219. Berenson makes no secret of his bias towards European art, the values of which he traces to the Greeks; all other, 'exotic', arts do not interest him: 'Compared with our art of the last sixty centuries with its endless variety of subject matter, of material, of kind and quality, every other art, Chinese included, is limited' (227).

52. Hawking 1996, 106-8; 148-49; Ridley 1995, 57-68; Price 1996, 33-35. 


\section{Prigogine \& Stengers 1984, 257-64.}

54. Elias 2000; the essay was originally written in English, but was first published in German translation, with additions, in 1984 .

55. Kellert 1993, 147-56.

56. Hayles 1990; see Shermer 1995, 62-63.

57. See Stewart 2002, 279-307, esp. 280-83.

58. On non-periodicity see Lorenz 1996, 20-24; non-predictability: Stewart 2002, 280-83, 348-51.

59. Analogies - 'general laws' associating material remains of the past with the cultural dynamics that generated them - were standard methodology in the systemic approach employed by New Archaeology (widely termed 'Middle-Range Theory'). This approach was mainly formulated by Binford, and is today retained mostly by ethnoarchaeology (though it can be traced, in a more or less haphazard way, in many an archaeological discourse). Middle Range Theory, and other such laws implicitly assuming that man and man-made communities remain unchanged through time and place, were criticized by Hodder (1986, 103-17; cf. 116: 'there can be no universal cultural relationship between statics and dynamics, because the historically contextual structuring principles intervene'. See Johnson 1999, 48-63; Renfrew \& Bahn 1991, Ch. 12.

60. Chaotic motion must be distinguished from randomness (McCloskey 1991, 32): non-linear dynamics allow personal and collective interventions (i.e. pro-active modelling that may harness the overall natural randomness), whereas conceding defeat to general randomness (in economics, in politics, in history) leads to fatalism, and the eventual cancellation of all human agency (including the need for history in the first place).

61. Cf. Prigogine \& Stengers 1984, 312-13: 'we know now that societies are immensely complex systems involving a potentially enormous number of bifurcations exemplified by the variety of cultures that have evolved in the relatively short span of human history'. See also Shermer 1995, 61-69; McGlade 1999, 152-54.

62. Feynman 1988, 10.

63. Wind 1963, 46; on the persistence of causal determinism see McGlade 1999, 148-49.

64. On Morelli see Wind 1963, 30-46; Wollheim 1973, 177201; Maginnis 1990. On Morelli and Beazley, see Kurtz 1985; Robertson 1985; Sparkes 1996, 91-102; Rouet 2001, 59-74; Boardman 2001, 128-38.

65. Reinach 1907; cf. Rouet 2001, 39.

66. Cf. the reaction of French archaeologist Edmond Pottier, Rouet 2001, 109-23.

67. Such as Aby Warburg's attack on Morrelli's method and ethics as early as 1903 (cf. Gombrich 1970, 142-43) or Edgar Wind's chapters in Art and Anarchy (1963).

68. Beazley 1918, 40-41. On Beazley's intellectual, social and academic milieu, see Boardman 2001, 131-33.

69. Cf. Vickers 1985, 122-28; Vickers 1987; Hoffmann 1979.

70. See Morris 1993, arguing that personal styles are discernible in prehistoric arts, based on art historical observations inspired by Morelli and Beazley; with several responses, for and against. Also on the subject of 'Masters' in Cycladic Art see GetzPreziosi 1977; Getz-Preziosi 1987; Renfrew 1991, 108-16.

71. Bruneau 1975 spoke against the quest for the individual in classical art but nobody listened. Vickers 1985 and Vickers \& Gill 1994 tried to contextualize Beazley and the method with mixed returns; Boardman 1987 and Cook 1987 contradict these views, and Robertson 1985, Robertson 1991, and elsewhere restates the Beazlean cause. Sparkes 1996, 102-13 reports on the pros and cons; Kurtz 1985 and Rouet 2001 study Beazley and his method avoiding undue polemics. Beard 1991; Whitley 1997; Turner 2000 add significant points of critique; Oakley 1998; Oakley 2004 clings to his hope 'of getting to know one individual from antiquity through his work', arguing that connoisseurship enables us to 'reach back in time and experience another's world through his works' (Oakley 1998, 210).

\section{Beazley 1922, 84 .}

73. See Gell 1998, 155-220 for the anthropological approach to an otherwise exclusively art historical subject. Also: Roe 1995; Voss \& Young 1995.

74. Gell 1998; on agency in archaeology see Dobres \& Robb 2000.

75. Foucault 1972, 131.

76. Hodder 1989 and esp. Hodder 1999, 170-71.

77. Huyssen 1986, 15.

78. Ginzburg 1983.

79. See Elsner 1990 and Shanks 1996, 39-41, where Ginzburg's ideas are used to analyze Beazley's method.

80. Trigger 1989, 61-65.

81. Fabian 1983, 37-52; 109-13.

82. Cf. this passage by Beazley, where the scholar addresses his audience as a deus ex machina: 'Thirty-eight vases will be assigned to the Berlin Master's hand. A list of these vases will first be given, arranged according to shape. The characteristics of the master's style will then be indicated. A further list of twenty-nine vases will follow. These are imitations. [...] They copy his style, some of them so closely that it is difficult to distinguish them from the master's own work'. (Beazley 1911, 277). Then follows a catalogue of the attributed works, with no other argumentation or explanation of the methodology employed. The reader is then expected to retrieve the results and use them on a 'no-questions-asked' basis.

83. Fabian 1983, 143.

84. Cf. Appadurai 1996, 130-35 on representation within the nationalist project (on which more below). 
85. Ginzburg 1983, 103-11.

86. Foucault 1977, esp. 195-228, a view further explored by Darnton (1984, 185-207) and White (1987, 83-103) among others.

87. According to sociologist Richard Sennett (Sennett 1992, 24-27) the conviction that an individual's 'real' nature is involuntarily disclosed by imperceptible, unconscious behavioural details, dates back to the last decades of the 19th c., when public life had invaded any notion of privacy. Under the influence of newly-established disciplines such as phrenology and criminology, it became widely acceptable that the individual was constantly attempting to defend his/her privacy by withdrawal and silence, against a society treating public disclosure as its constituent right. According to this new code of social contact, any public display of personal feelings or sentiments exposes the subject's inner self to the prying eyes of an ever so curious society.

88. White 1987, 86.

89. Cf. Gellner 1983, 19-24.

90. Bourdieu 1993, 76-77.

91. Barthes 1977, 142-48.

92. Foucault 1984b, an essay first translated in English from the earlier French version in 1979.

93. Foucault analyzes the work De viris illustribus by St Jerome (AD 340-420), though earlier examples are also extant, such as Lives of the Philosophers by Greek scholar Flavius Philostratus (2nd-3rd c. AD), where individual style is treated as a criterion for accepting or rejecting a certain text as part of an individual author's canon.

94. Darnton 1984, 186. On modern science as taxonomy, see Foucault 1970, 50-58.

95. Cf. Beazley 1918, vi.: 'However obscure he may be, the artist cannot escape detection if only sufficient delicate tests be applied'.

\section{REFERENCES}

Anderson B. 1991: Imagined Communities: Reflections on the Origin and Spread of Nationalism (2nd revised edition; London and New York).

Appadurai A. 1996: Modernity at Large: Cultural Dimensions of Globalization (Minneapolis and London).

Barthes R. 1977: Image Music Text (transl. by S. Heath; London).

Bell E.T. 1986: From peasant to snob: Laplace, in: Men of
96. Oakley 1998 admits as much: unaware (presumably) of Foucault, he takes pride in using the method applied to 'criminal personalities' by F.B.I. profilers - 'if you want to understand Picasso, you have to study his art. If you want to understand the criminal personality, you have to study the crime', he says, quoting one such profiler's master class (212).

97. Jameson 2002, 31-41, esp. 34-35.

98. Wind 1963, 28.

99. Hawking 1996, 128-29; Price 1996, 97-99.

100. Fabian 1983, 37-69.

101. Meskell 1998, 3.

102. Herzfeld 1987, 20-21; Gourgouris 1996, 140-54.

103. Calotychos 2003, 23-59.

104. Derrida 1976, 65-73.

105. Fabian 1983, 16-17.

106. Said 1994, 31-49.

107. Herzfeld 1987, 13-16.

108. Herzfeld 1987, 20-21; see also Calotychos 2003, 2353.

109. Anderson 1991, esp. 163-85.

110. Calotychos 2003, 47-50.

111. Meskell 1998, 4-5; See also Chatterjee 1993, 3-13; 3675 and Bhabha 1994, 94-120, who also resent the notion that the post-colonial world is bound to a 'perpetual consumption of modernity'. On Greece, and its 'indigenous Hellenism', see Hamilakis 2007, 112-19.

112. Cf. Anderson 1991, 182.

113. See Lowenthal 1988; Hamilakis \& Yalouri 1996.

114. Appadurai 1996, 178-99.

115. Cf. Brennan 1990.

Mathematics: the Lives and Achievements of the Great Mathematicians from Zeno to Poincaré (New York) 172-82.

Beard M. 1991: Adopting an approach. II, in: Rasmussen T. \& Spivey N. (eds), Looking at Greek Vases (Cambridge) $12-35$.

Beazley J.D. 1910: Kleophrades, Journal of Hellenic Studies 30, 38-68. 
Beazley J.D. 1911: The Master of the Berlin Amphora, Journal of Hellenic Studies 31, 276-95.

Beazley J.D. 1918: Attic Red-figured Vases in American Museums (London and Cambridge, MA).

Beazley J.D. 1922: Citharoedus, Journal of Hellenic Studies 42, 70-98.

Berenson B. 1950: Aesthetics and History (London).

Berlin I. 1999: The Roots of Romanticism (Princeton).

Berlin I. 2000: Three Critics of the Enlightenment: Vico, Hamann, Herder (Princeton).

Bhabha H.K. 1994: The Location of Culture (London and New York).

Boardman J. 1987: Silver is white, Revue Archèologique, 279-95.

Boardman J. 2001: The History of Greek Vases (London).

Borbein A.H. 1996: Polykleitos, in: Palagia O. \& Pollitt J.J. (eds), Personal Styles in Greek Sculpture. Yale Classical Studies 30 (New Haven) 66-90.

Borbein A.H. et al. (eds) 2000: Klassische Archäologie: eine Einführung (Berlin).

Bourdieu P. 1993: The Field of Cultural Production: Essays on Art and Literature (ed. by R. Johnson; New York).

Brennan T. 1990: The national longing for form, in: Bhabha H.K. (ed.), Nation and Narration (London and New York) 44-70.

Brown D.A. 1979: Berenson and the Connoisseurship of Italian Painting (Washington).

Bruneau P. 1975: Situation méthodologique de l'histoire de l'art antique, L'antiquité classique 44, 425-87.

Burckhardt J. 1990: The Civilization of the Renaissance in Italy (London).

Calotychos V. 2003: Modern Greece: a Cultural Poetics (Oxford and New York).

Cassidy D. 1992: Heisenberg, uncertainty and the quantum revolution, Scientific American 266, 106-12.

Chatterjee P. 1993: The Nation and its Fragments: Colonial and Postcolonial Histories (Princeton).

Childs W.A.P. 2005: Stil als Inhalt statt als Künstlersignatur, in: Strocka V.M. (ed.), Meisterwerke: Internationales Symposion anläßlich des 150. Geburtstages von Adolf Furtwängler, Freiburg im Breisgau, 30 Juni - 3 Juli 2003 (Munich) 235-43.

Cook R.M. 1987: Artful crafts: a commentary, Journal of Hellenic Studies 107, 169-71.
Darnton R. 1984: The Great Cat Massacre and Other Episodes in French Cultural History (London).

Derrida J. 1976: Of Grammatology (transl. by G. Chakravorty Spivak; Baltimore and London).

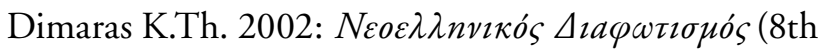
edition; Athens).

Dobres M.A. \& Robb J.E. (eds) 2000: Agency in Archaeology (London and New York).

Elias N. 2000: Über die Zeit: Arbeiten zur Wissenssoziologie II (Munich).

Elsner J. 1990: Significant details: systems, certainties and the art-historian as detective, Antiquity 64, 950-52.

Fabian J. 1983: Time and the Other: how Anthropology makes its Object (New York).

Feynman R.P. 1988: QED: the Strange Theory of Light and Matter (Princeton).

Foucault M. 1970: The Order of Things: an Archaeology of the Human Sciences (New York).

Foucault M. 1972: The Archaeology of Knowledge and the Discourse on Language (transl. by A.M. Sheridan Smith; New York).

Foucault M. 1977: Discipline and Punish: the Birth of the Prison (transl. by A. Sheridan; New York).

Foucault M. 1984a: What is Enlightenment?, in: Rabinow P. (ed.), The Foucault Reader (New York) 32-50.

Foucault M. 1984b: What is an author?, in: Rabinow P. (ed.), The Foucault Reader (New York) 101-20.

Furtwängler A. 1893: Meisterwerke der griechischen Plastik: Kunstgeschichtliche Untersuchungen (Leipsig and Berlin).

Furtwängler A. 1895: Masterpieces of Greek Sculpture: a Series of Essays on the History of Art (London).

Gell A. 1998: Art and Agency: an Anthropological Theory (Oxford).

Gellner E. 1983: Nations and Nationalism (Ithaca).

Getz-Preziosi P. 1977: Cycladic sculptors and their methods, in: Thimme J. (ed.), Art and Culture of the Cyclades (Karlsruhe) 71-91.

Ginzburg C. 1983: Morelli, Freud and Sherlock Holmes: clues and the scientific method, in: Eco U. \& Sebeok T. (eds), The Sign of Three: Dupin, Holmes, Peirce (Bloomington) 81-118.

Gombrich E.H. 1970: Aby Warburg: an Intellectual Biography (London).

Gourgouris S. 1996: Dream Nation: Enlightenment, Colonization and the Institution of Modern Greece 
(Stanford).

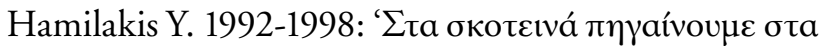

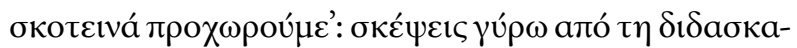

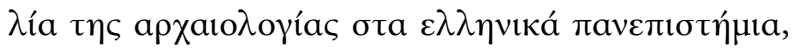
Horos 10-12, 585-604.

Hamilakis Y. 2004a: Archaeology and the politics of pedagogy, World Archaeology 36, 287-309.

Hamilakis Y. 2004b: The fragments of modernity and the archaeologies of the future, Modernism/Modernity $11,55-59$.

Hamilakis Y. 2007: The Nation and its Ruins: Antiquity, Archaeology, and National Imagination in Greece ( $\mathrm{Ox}-$ ford).

Hamilakis Y. \& Yalouri E. 1996: Antiquities as symbolic capital in modern Greek society, Antiquity 70, 117-29.

Hawking S. 1996: A Brief History of Time (New York).

Hayles N.K. 1990: Chaos Bound: Orderly Disorder in Contemporary Literature and Science (Ithaca).

Herzfeld M. 1986: Ours Once More: Folklore, Ideology, and the Making of Modern Greece (New York).

Herzfeld M. 1987: Anthropology Through the LookingGlass: Critical Ethnography in the Margins of Europe (Cambridge).

Hodder I. 1986: Reading the Past: Current Approaches to Interpretation in Archaeology (Cambridge).

Hodder I. 1989: Writing archaeology: site reports in context, Antiquity 63, 268-74.

Hodder I. 1992: Theory and Practice in Archaeology (London and New York).

Hodder I. 1999: The Archaeological Process: an Introduction (Oxford).

Hoffmann H. 1979: In the wake of Beazley: prolegomena to an anthropological study of Greek vase-painting, Hephaistos 1, 61-70.

Huyssen A. 1986: After the Great Divide: Modernism, Mass Culture, Postmodernism (Bloomington and Indianapolis).

Jameson F. 2002: A Singular Modernity: Essay on the Ontology of the Present (New York).

Jenkins I. \& Sloan K. 1996: Vases and Volcanoes: Sir William Hamilton and his Collection (London).

Johnson M. 1999: Archaeological Theory: an Introduction (Oxford).

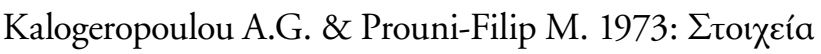

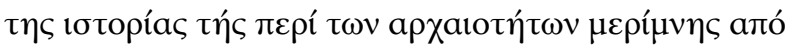

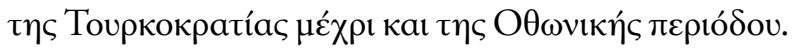

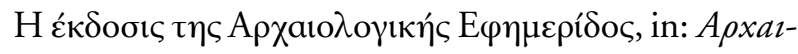

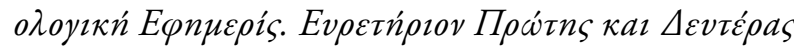

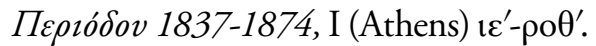

Kellert S.H. 1993: In the Wake of Chaos (Chicago).

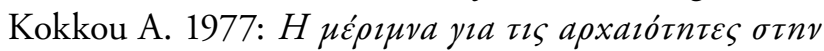

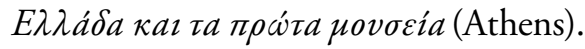

Kuhn T.S. 1985: The Copernican Revolution: Planetary Astronomy in the Development of Western Thought (London and Cambridge, MA).

Kurtz D.C. 1985: Beazley and the connoisseurship of Greek vases, Greek Vases in the J. Paul Getty Museum 2, 237-50.

Lowenthal D. 1988: Classical antiquities as national and global heritage, Antiquity 62, 726-35.

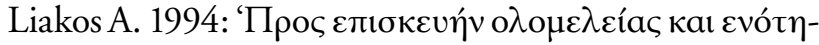

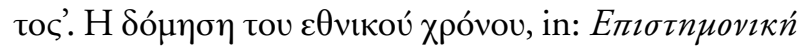

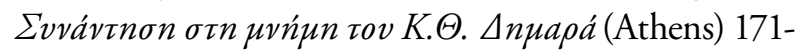
99.

Lorenz E. 1996: The Essence of Chaos: the Jessie and John Danz Lecture Series (Washington).

Lyotard J.-F. 1984: The Postmodern Condition: a Report on Knowledge (transl. by G. Bennington \& B. Massumi; Minneapolis).

Maginnis H.B.J. 1990: The role of perceptual learning in connoisseurship: Morelli, Berenson, and beyond, Art History 13, 104-17.

McCloskey D.N. 1991: History, differential equations, and the problem of narration, History and Theory 30, 21-36.

McGlade J. 1999: The times of history: archaeology, narrative and non-linear causality, in: Murray T. (ed.), Time and Archaeology (London) 139-63.

Meskell L. 1998: Archaeology matters, in: Meskell L. (ed.), Archaeology Under Fire: Nationalism, Politics, and Heritage in the Eastern Mediterranean and Middle East (London and New York) 1-12.

Morris C. 1993: Hands up for the individual! The role of attribution studies in Aegean prehistory, Cambridge Archaeological Journal 3, 41-66.

Oakley J.H. 1998: Why study a Greek vase-painter? - A response to Whitley's 'Beazley as a theorist', Antiquity 72, 209-12.

Oakley J.H. 2004: New vases by the Achilles Painter and some further thoughts on the role of attribution, in: Keay S. \& Moser S. (eds), Greek Art in View: Essays in honour of Brian Sparkes (Oxford). 
Palagia O. \& Pollitt J.J. (eds) 1996: Personal Styles in Greek Sculpture. Yale Classical Studies 30 (New Haven).

Peckham R.S. 2001: National Histories, Natural States: Nationalism and the Politics of Place in Greece (London and New York).

Potts A. 1994: Flesh and the Ideal: Winckelmann and the Origins of Art History (New Haven and London).

Price H. 1996: Time's Arrow and Archimedes' Point: New Directions for the Physics of Time (Oxford).

Prigogine I. \& Stengers I. 1984: Order out of Chaos: Man's New Dialogue with Nature (New York).

Reinach S. 1907: Adolphe Furtwängler, Chronique des Arts, 310.

Reisch G. 1991: Chaos, History, and Narrative, History and Theory 30, 1-20.

Renan E. 1890: L'Avenir de la science: Pensées de 1848 (Paris).

Renfrew C. 1991: The Cycladic Spirit: Masterpieces from the Nicholas P. Goulandris Collection (New York).

Renfrew C. \& Bahn P. 1991: Archaeology: Theories, Methods and Practice (London).

Ridley B.K. 1995: Time, Space and Things (3rd edition; Cambridge).

Robertson M. 1985: Beazley and Attic vase painting, in: Kurtz D.C. (ed.), Beazley and Oxford (Oxford) 19-30.

Robertson M. 1991: Adopting an approach. I, in: Rasmussen T. \& Spivey N. (eds), Looking at Greek Vases (Cambridge) 1-12.

Roe P.G. 1995: Style, society, myth, and structure, in: Carr C. \& Neitzel J.E. (eds), Style, Society, and Person: Archaeological and Ethnological Perspectives (New York and London) 27-76.

Rouet P. 2001: Approaches to the Study of Attic Vases: Beazley and Pottier (Oxford).

Said E.W. 1994: Orientalism (2nd edition; New York).

Sennett R. 1992: The Fall of Public Man (New York and London).

Shanks M. 1996: Classical Archaeology of Greece: Experiences of the Discipline (London and New York).

Shermer M. 1995: Exorcising Laplace's demon: chaos and antichaos, history and metahistory, History and Theory
34, 59-83.

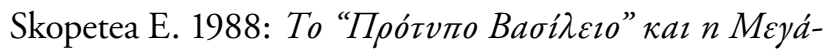

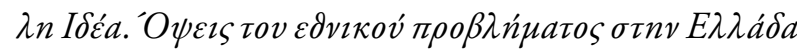
(1830-1880) (Athens).

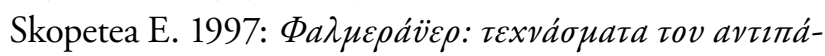
$\lambda$ ov déovৎ (Athens).

Sparkes B.A. 1996: The Red and the Black: Studies in Greek Pottery (London and New York).

Stewart I. 2002: Does God Play Dice? The New Mathematics of Chaos (2nd revised edition; Oxford).

Trigger B.G. 1989: A History of Archaeological Thought (Cambridge).

Turner M. 2000: Attribution and iconography, Mediterranean Archaeology 13, 55-66.

Veloudis G. 1982: O Jakob Philipp Fallmerayer kaı $n$

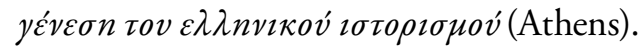

Vickers M. 1985: Artful crafts; the influence of metalwork on Athenian painted pottery, Journal of Hellenic Studies 105, 108-28.

Vickers M. \& Gill D. 1994: Artful Crafts: Ancient Greek Silverware and Pottery (Oxford).

Voss J.A. \& Young R.L. 1995: Style and the self, in: Carr C. \& Neitzel J.E. (eds), Style, Society, and Person: Archaeological and Ethnological Perspectives (New York and London) 77-99.

Voutsaki S. 2002: The 'Greekness' of Greek prehistory: an investigation of the debate 1876-1900, Pharos 10, 105-22.

Voutsaki S. 2003: Archaeology and the construction of the past in nineteenth century Greece, in: Hokwerda H. (ed.), Constructions of Greek Past: Identity and Historical Consciousness from Antiquity to the Present (Groningen) 231-55.

White H. 1987: The Content of the Form: Narrative Discourse and Historical Representation (Baltimore).

Whitley J. 1997: Beazley as a theorist, Antiquity 71, 4047.

Wollheim R. 1973: On Art and the Mind (London and Cambridge, MA).

Wind E. 1963: Art and Anarchy (London). 